\title{
Responses of the fish community in a eutrophicated lake to long-term food web management assessed by multiple sampling methods
}

\author{
Martti Rask • Tommi Malinen • Mikko Olin • Heikki Peltonen • \\ Jukka Ruuhijärvi $\cdot$ Sami Vesala $\cdot$ Jaana Hietala
}

Received: 19 June 2019/Revised: 24 March 2020/Accepted: 28 March 2020/Published online: 18 April 2020

(C) The Author(s) 2020

\begin{abstract}
Fish community responses to long-term mass removal of planktivorous fish from eutrophicated Lake Tuusulanjärvi were examined during 1996-2018 by gill net test fishing, hydroacoustics with simultaneous trawling, virtual population analysis (VPA) and fish growth measurements. The gillnet catches of white bream and roach increased first while bream and bleak decreased but recovered in the early 2000s. Perch and pikeperch increased but ruffe decreased and remained low. According to hydroacoustics, pelagic
\end{abstract}

Guest editors: Tom Jilbert, Raoul-Marie Couture,

Brian J. Huser \& Kalevi Salonen / Restoration of eutrophic lakes: current practices and future challenges

M. Rask ( $\square)$

University of Helsinki, Lammi Biological Station,

16900 Lammi, Finland

e-mail: martti.rask@helsinki.fi

T. Malinen

Department of Environmental Sciences, University of

Helsinki, P.O. Box 65, 00014 Helsinki, Finland

M. Olin · J. Ruuhijärvi $\cdot$ S. Vesala

Natural Resources Institute Finland, P.O.Box 2,

00791 Helsinki, Finland

\section{H. Peltonen}

Finnish Environment Institute, Latokartanonkaari 11, 00790 Helsinki, Finland

\section{J. Hietala}

Mid-Uusimaa Board for Water Protection Control,

Kultasepänkatu 4, 04250 Kerava, Finland fish biomass decreased. Smelt was the most abundant species at the beginning and the end of the monitoring period but bream dominated the fish biomass in most years. VPA calculations indicated a five- and threefold increase in the biomass of bream and white bream, respectively, during 2005-2011. Significant increases appeared in the growth of perch, bream and roach. Overall, the responses in the fish community structure and fish abundance to the food web management were slight and mostly masked by changes in reproduction and growth of fish and annual variability in environmental conditions such as temperature and water turbidity. Gillnet test fishing and echo sounding complemented each other well in monitoring the effects of management fishing. Where bream is one of the dominant species VPA is also recommended.

Keywords Biomanipulation - Lake restoration . Gillnet test fishing · Hydroacoustics · VPA · Fish growth

\section{Introduction}

Eutrophication due to scattered or diffuse loading of nutrients, in particular from agriculture and forestry, is now considered the most severe environmental distuturbance to Finnish lakes. Biomanipulation by means of mass removal of planktivorous fish has been a major tool for restoring eutrophicated lakes in Europe and 
North America during the last decades (Carpenter et al., 1985; Benndorf, 1990; Horppila et al., 1998; Peltonen et al., 1999a; Sammalkorpi, 2000; Sarvala et al., 2000; Ruuhijärvi et al., 2005; Olin et al., 2006; Søndergaard et al., 2007; Gulati et al., 2008; Bernes et al., 2015).

Lake Tuusulanjärvi is the largest lake of the River Vantaa drainage basin, located in the densely populated area of southernmost Finland, $30 \mathrm{~km}$ north of Helsinki. The surface area of the lake is $6 \mathrm{~km}^{2}$, mean depth $3.2 \mathrm{~m}$ and maximum depth $10 \mathrm{~m}$. The drainage area $\left(92 \mathrm{~km}^{2}\right)$ consists of forest $(40 \%)$, arable land $(35 \%)$ and urban area (20\%). Clay soil makes up $65 \%$ of the drainage area. Symptoms of eutrophication of this originally slightly dystrophic lake were already recorded in the 1930s (Järnefelt, 1937) and from the mid 1950s rapid eutrophication took place due to increased nutrient loading from settlements and agriculture. Sewage discharge from purification plants was stopped in 1979 but the lake remained hypertrophic due to high nutrient load from agriculture and forestry and the high internal loading (Pekkarinen, 1990). The first efforts to restore the lake were intiated in the early 1970 s, including aeration of the water column.

The recent joint restoration project of Lake Tuusulanjärvi was organized in 1999 under the lead of The Mid-Uusimaa Board for Water Protection Control (KUVES). Activities in the lake catchment included support and advice for water protection measures to local farmers and construction of water protection wetlands and sedimentation pools to the brooks and rivers to decrease the nutrient load from the drainage area to the lake. In the lake, biomanipulation by removing planktivorous cyprinid fish and aeration of the water column with Mixox pumps (Saarijärvi \& Lappalainen, 2004) were regular measures to counteract the harmful effects of eutrophication (Hietala \& Pekkarinen, 2017). Although the ecological status of Lake Tuusulanjärvi is still poor in the classification of the EU Water Framework Directive (WFD), and the external and internal nutrient load still clearly exceed the critical limits for reduction of the level of eutrophication (Luodeslampi et al., 2017), positive development in water quality has taken place since the 1970s as indicated by decreased total phosphorus concentration and phytoplankton biomass. The high late summer phytoplankton biomasses of $20-80 \mathrm{mg}$ $1^{-1} \mathrm{WM}$ (wet mass) that were common from the $1970 \mathrm{~s}$ to the mid 1990s (Järvinen \& Lepistö, 2017) have been replaced by biomasses continuously $<20 \mathrm{mg} \mathrm{l}^{-1}$ and annual mean values $<10 \mathrm{mg} \mathrm{l}^{-1}$ (Järvinen \& Lepistö, 2017; KUVES, unpublished), which indicate success in the restoration program.

In this paper, we present results from 20 year studies of the responses of fish populations to the mass removal of cyprinid fish. We hypothesized that biomanipulation decreases the fish biomass of the lake and result in (1) smaller biomass catches of gillnet test fishing and (2) lower hydroacoustic fish biomass estimates, while targeting cyprinid species in the management fishing (3) increases the proportion of percids and predatory species in the conditions of no changes in fishing pressure. Furthermore, simultaneous application of different methods in monitoring the development of the fish community during the study period provided an improved opportunity to evaluate the reliability of the results.

\section{Materials and methods}

\section{Management fishing}

Management fishing in Lake Tuusulanjärvi was started in 1997 to decrease the occurrence of algal blooms in the lake. The main method in fish removal was autumn seining of cyprinid fish. In the years 1998 , 1999, 2003 and 2007, seining was conducted also in winter and spring. Fykenets were used for fishing during spawning of cyprinids in spring during 1997-2005. Subsequently, the fish removal was conducted solely by autumn seining in SeptemberNovember. Target catch was set to WM of $200 \mathrm{~kg} \mathrm{ha}^{-1}$ in 3 years according to the successful biomanipulation of L. Vesijärvi (Horppila et al., 1998). For seining, the fish shoals were localized by hydroacoustics and seining conducted by professional fishermen hired by KUVES. The mass of removed fish was measured volumetrically as number of specific barrels with known weight full of fish. The species composition was determined from subsamples of 10 to $30 \mathrm{~kg}$. For technical details of the fishing operations and gear, see Sammalkorpi (2000).

\section{Gillnet sampling}

Gillnet monitoring of the fish community in Lake Tuusulanjärvi was started in 1996. In 1998-2009 test 
fishing was carried out annually and later every third year $(2012,2015,2018)$ as a part of the monitoring programme of WFD. Sampling was conducted five times per year during July-August, 11 nets each time. NORDIC multimesh survey nets (Appelberg et al. 1995) were used and stratified random sampling was applied proportional to the area of the depth zones (CEN, 2005; Olin et al., 2006). The annual number of gillnet nights (from ca. 8 pm to 8 am) was 46 in 1996 and 55 in the other years. The numbers of benthic, pelagic and metalimnetic gillnets were 40, 10 and 5, respectively, but 38 benthic and 8 pelagic nets in 1996 . The between-year differences in gillnet total BPUE (WM per unit effort $=\mathrm{kg}$ fish per gillnet night $)$ and the BPUE of individual fish species were tested with a generalized mixed linear model (McCullagh \& Nelder, 1989). In the model, year (1996-2018) and depth zone (0-3 m bottom, 3-6 $\mathrm{m}$ bottom and surface, 6-10 m bottom, metalimnion and surface) were fixed factors and fishing date (nested in year) was a random factor. The link function was logarithmic and the probability distribution was negative binomial. Tukey-Kramer's test was used for pairwise comparisons. The yearly trends in the estimated BPUEs were tested with linear regression. For comparison of gillnet BPUE and hydroacoustic biomass estimates, only catches from nets placed in depth zones $>3 \mathrm{~m}$ were included to increase the comparability of the areal coverage in the two methods.

\section{Hydroacoustic fish stock assessment}

The pelagic fish biomass was assessed with yearly echo-surveys from the beginning of the mass removal. From 1999 simultaneous trawling was conducted in order to determine species composition and length distribution of each species, and to estimate fish biomass at the surface blind zone of the echo sounder. During the first years, the surveys were conducted in late autumn. From 2004 the surveys were carried out in late August-early September, when the young-ofthe-year fish have achieved sizes allowing their detection, and usually the weather conditions are more suitable for echo sounding than in late autumn.

Hydroacoustic sampling was done during the daytime along nine equidistant transects at intervals of $200 \mathrm{~m}$ covering $>5 \mathrm{~m}$ deep areas (Malinen, 2018). The location of the first transect was randomized. The acoustic equipment consisted of a SIMRAD EY-500 echo sounder equipped with a split-beam transducer ES120-7C (operating frequency $120 \mathrm{kHz}$ and beam opening angle $7^{\circ}$ at $-3 \mathrm{~dB}$ level). Pulse duration was set to $0.3 \mathrm{~ms}$ and minimum target strength to $-65 \mathrm{~dB}$. The transducer was calibrated using a standard copper sphere with SIMRAD LOBE-program. The trawling was conducted with two boats in high-density areas and in randomized sites (surface trawling). The two trawls that were used had a height of 2 and 4 meters and width of 5 and 8 meters, respectively, and the cod-end mesh size was $3 \mathrm{~mm}$. From each haul, either the whole catch or a random sample was taken for analysis.

The fish density of each transect was computed by echo integration. The integrator threshold was set to $-60 \mathrm{~dB}$. The total backscattering coefficient $\left(s_{\mathrm{a}}\right.$, MacLennan et al., 2002) was calculated by EP500 software and the mean cross-section $(\sigma)$ was determined either (1) using the length-distribution of trawl catches and a relationship between fish length and target strength (Peltonen et al., 2006; Malinen, 2018), or (2) using the target strength distribution obtained with the echo sounder. The fish density was computed as $s_{\mathrm{a}} / \sigma$ (Simmonds \& MacLennan, 2005). The density was divided into species-specific estimates based on species distributions of trawl catches and these were converted to biomass estimates based on the wet masses of each species. The mean density and biomass in the study area were computed using transect lengths as weights (Shotton \& Bazigos, 1984) and their 95\% confidence limits were estimated based on Poissondistribution (Jolly \& Hampton, 1990). Due to the lack of unbiased method for combining the variances of trawling and acoustic estimates, the confidence intervals were computed only for those surveys where the fish biomass at the surface blind zone was negligible.

Virtual population analysis

In the VPA cohort analysis approach (Pope, 1972) was applied. It assumes that catches were taken during a short period annually. The method was used for the stocks of the three most abundant cyprinid species, bream (Abramis brama L.), white bream (Abramis björkna L.) and roach (Rutilus rutilus L.), during the years 2005-2011. The numerical catch of each agegroup was estimated using the statistics for the total seine yield and random samples from seine catches. Random samples with a frame of $1 \mathrm{~m}^{2}$ square were 
taken from more than $90 \%$ of hauls (Malinen et al., 2017). The ages of fish were determined mainly from scales but confirmed from cleithra in uncertain cases. During the years 2005-2009, ages were determined yearly from ca. 1000 bream, 450-1000 white bream and 400-1000 roach. During the years 2010-2011, the age-length key (Ricker, 1975) was applied and the number of age determinations was reduced to $150-300$ for each species and year. To determine the age structure of the catches, the age-length key was applied to samples consisting of 300-3700 length measurements for each species and year (Malinen et al., 2017).

The youngest fish were excluded from the cohort analysis, because their low catches indicated very low catchability and also the natural mortality rates in young age groups are poorly known. The analyses were started from the age two for bream, three for white bream and one for roach. Instantaneous natural mortality rates were assumed to be 0.15 for bream, 0.2 for white bream and 0.3 for roach (Horppila \& Peltonen, 1994). The age-specific terminal fishing mortality rates (fishing mortality during the last year of the analysis) for year 2011 were estimated as an average over the years 2005-2010 for roach. However, exceptionally high bream and white bream catches in 2011 suggested that fishing mortality (and hence the catchability) must have been appreciably higher than the average, so for these species the terminal fishing mortalities were estimated based on the assumption of similar catchabilities as in the year 2009 when very high catches were also obtained. Thus, the terminal fishing mortalities were presented as a product of catchability and effort (the count of seine hauls). These equations were included in the analysis, and the solutions for age-specific stock sizes were sought iteratively (Malinen et al., 2017). Finally, the biomasses of stocks were calculated based on yearly and age-specific stock sizes and mean wet masses of fish.

\section{Growth of fish}

To evaluate possible responses in fish growth to the food web manipulation, samples for age determination of four important and abundant species were collected from year-classes born before (1988-1997) and after (1998-2008) the onset of the biomanipulation. These included perch (Perca fluviatilis L.) ( $n=234$ born before and 492 born after the onset of manipulation, pikeperch (Sander lucioperca L.) ( $n=256$ and 371), roach $(n=339$ and 476$)$ and bream $(n=67$ and 203, respectively). The age of roach and pikeperch was determined from scales and growth back-calculated according to the method of Fraser and Lee (Bagenal \& Tesch, 1978) with the length of fish at scale formation $19 \mathrm{~mm}$ for roach and $44 \mathrm{~mm}$ for pikeperch. The age determination and growth back-calculation of perch was done from the opercular bone and those of bream from the cleithrum (Bagenal \& Tesch, 1978; Raitaniemi et al., 1988; Ruuhijärvi et al., 1996; Horppila \& Nyberg, 1999). The significance of differences in mean annual length increments of fish born before and after onset of the management fishing were assessed with $t$ tests.

\section{Results}

Management fishing

Altogether, $1616 \mathrm{~kg} \mathrm{ha}^{-1}$ of planktivorous fish was removed from the lake during the 22 year biomanipulation 1997-2018. Annual catches varied between 30 and $180 \mathrm{~kg} \mathrm{ha}^{-1}$. The highest catches of $>100 \mathrm{~kg}$ ha $^{-1}$ occurred in 1997-1999, 2003 and 2009 (Fig. 1). The mean catch per haul was $2500 \mathrm{~kg}$ in 1997 and fluctuated between 300 and $1100 \mathrm{~kg}$ since then.

After the high removal catches in 1997-1999, two to four-year periods of lower (30 to $50 \mathrm{~kg} \mathrm{ha}^{-1}$ ) and higher catches (50-140 kg ha ${ }^{-1}$ ) alternated. Cyprinid species dominated the catches throughout the study period with an annual proportion of 59 to $91 \%$. Bream and roach were the most abundant species (29 and $28 \%$ of total yields in 1997-2018) followed by white bream, smelt (Osmerus eperlanus L.) and perch with biomass proportion of $8-9 \%$ each. Management fishing appeared to have no direct effect on the water quality (unpublished data from KUVES) in Tuusulanjärvi as no significant correlations were found between the removal catches and chlorophyll $a$, total phytoplankton biomass or the biomass of blue green algae of next growing season. Instead, the turbidity of water correlated negatively with the autumn seining catches of roach $\left(r^{2}=0.33, P<0.01\right)$ and perch 


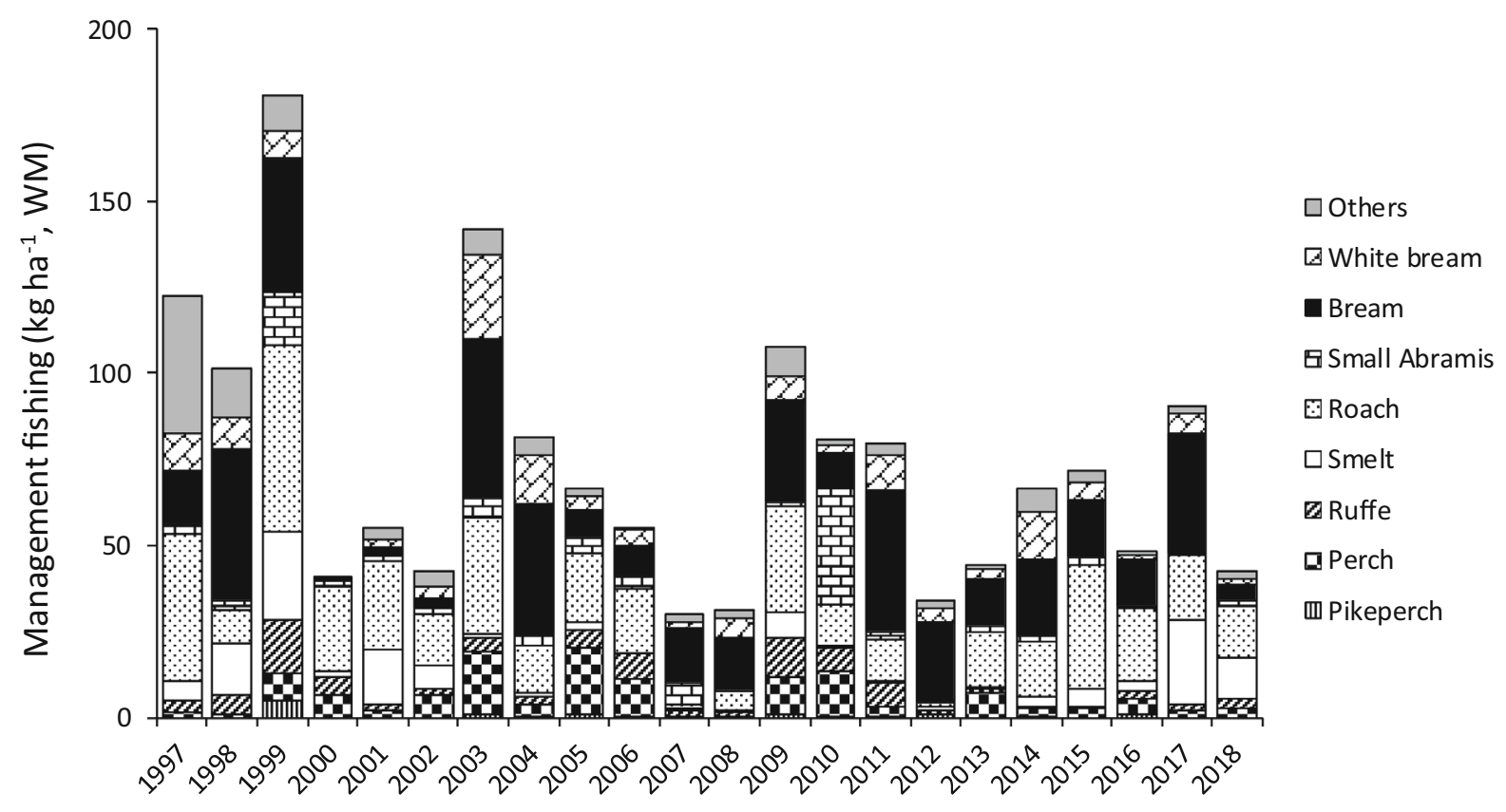

Fig. 1 Annual catches from management fishing in Lake Tuusulanjärvi during 1997-2018. The category Others mainly comprised of bleak and rudd

$\left(r^{2}=0.19, P<0.05\right)$, but not the catches of bream, white bream, pikeperch and smelt.

\section{Gillnet fishing}

The gillnet catches (BPUE) were around 1-2 kg in the first years of the project (Fig. 2). Despite high removal catches of planktivorous fish $\left(>100 \mathrm{~kg} \mathrm{ha}^{-1}\right)$ in the years of 1997-1999, there was an increasing trend in the total BPUE from 1996 until the years 2002 and 2003 (linear regression: $F_{1,6}=36.68$, slope $=36.68$, $\left.r^{2}=0.88, P=0.001\right)$ with mean BPUE of $4 \mathrm{~kg}$ per net (geometric means). From 2004 onwards, the total BPUE varied between 2 and $3 \mathrm{~kg}$ with no clear trend. The low catches in 2008 were apparently related to the cold and rainy summer and turbid water. The proportion of cyprinids in gillnet catches was 70-80\% and that of percids $15-25 \%$ in most years of the research period. The proportion of predatory fishes (pike, pikeperch and perch $>15 \mathrm{~cm}$ in total length) was in most years $10-18 \%$ of the BPUE without any trend during the 1996-2018. The most abundant species in gillnet catches were roach (mean annual BPUE $0.2-1.2 \mathrm{~kg}$ ) and white bream (BPUE 0.2-1.1 kg), followed by perch (BPUE $0.1-0.5 \mathrm{~kg}$ ), pikeperch (BPUE 0.1-0.5 kg), bream (BPUE 0.04-0.3 kg) and rudd (Scardinius erythropthalmus L.), BPUE 0-0.6 kg (Fig. 2).

There were species-specific differences in the mean BPUEs during the project (Fig. 3). The BPUE of white bream and perch had an increasing trend during 1996-2002 and then fluctuated irregularly (linear regression, white bream: $F_{1,6}=11.61$, slope $=0.30$, $r^{2}=0.70, P=0.019$, and linear regression, perch: $F_{1,6}=94.60$, slope $\left.=0.32, r^{2}=0.95, \quad P<0.001\right)$. Roach BPUE fluctuated irregularly. Bream BPUE first decreased, then increased, and was highest in 2003 and 2004 being higher than the BPUE of any of the previous years (Tukey-Kramer: $P<0.01$ in all comparisons). Pikeperch BPUE increased and in 2002 was higher than in any of the previous years (TukeyKramer: $P<0.05$ in all comparisons), and thereafter fluctuated irregularly. The BPUE of bleak (Alburnus alburnus L.) first decreased and in 2000-2002 was lower than in the previous years (Tukey-Kramer: $P<0.01$ in all comparisons), but recovered in 2003 (Tukey-Kramer: $P<0.01$ in all comparisons). Ruffe (Gymnocephalus cernuus L.) decreased after the first year of management fishing and remained at lower levels after that. The gillnet catches suggested a decreased smelt abundance in 2003-2008 but a recovery in recent years. The catch of smelt in 2018 


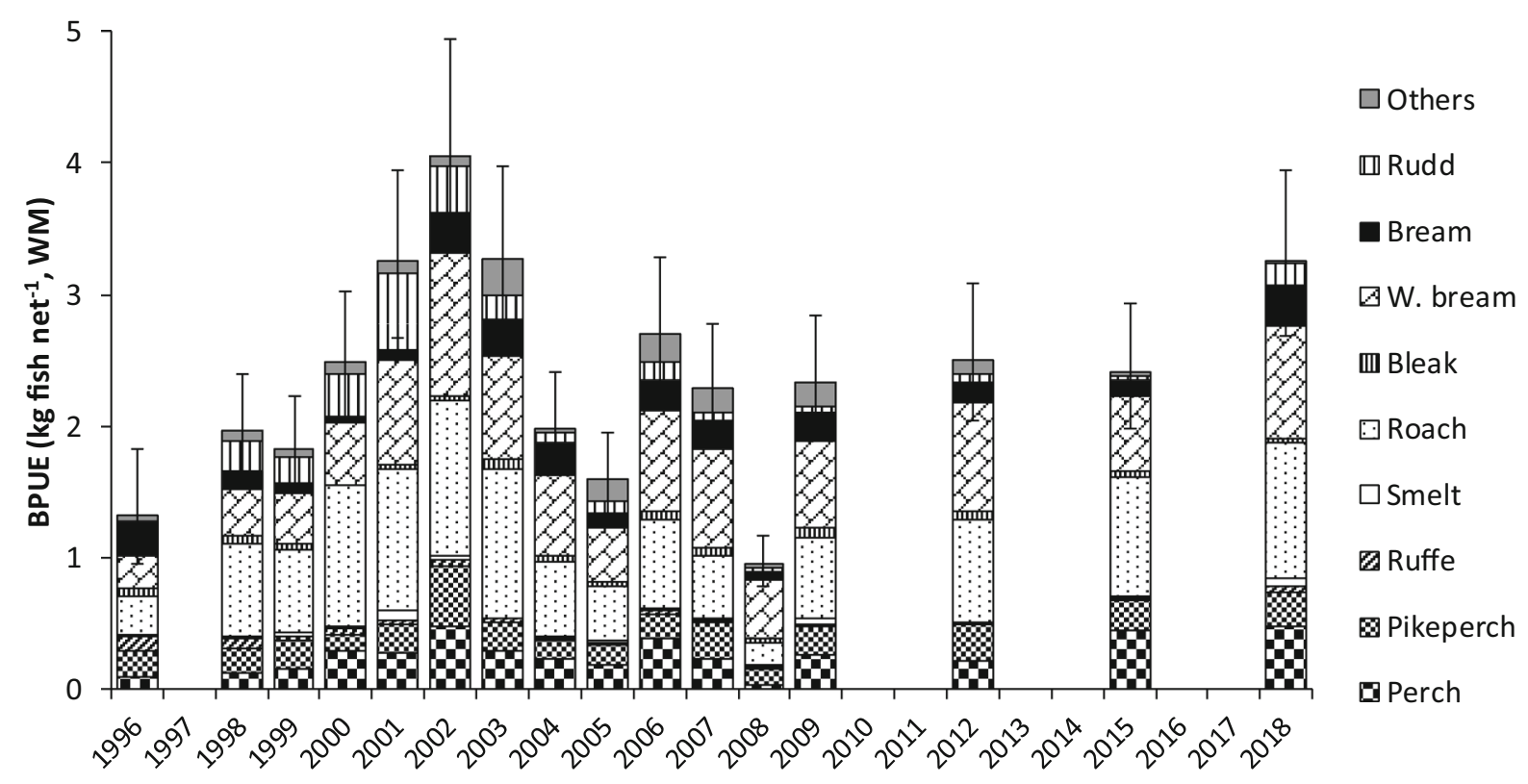

Fig. 2 Proportion of different fish species in annual total BPUE (geometric mean $+95 \%$ confidence limits) from NORDIC gillnets in Lake Tuusulanjärvi during 1996-2018. The category Others comprised of pike (Esox lucius L.), tench (Tinca tinca L.)

was significantly higher (Tukey-Kramer: $P<0.01$ in all comparisons) than the catch in 2003-2008 (Fig. 3).

The annual mean total BPUE of littoral nets (depth $<3 \mathrm{~m}$ ) were significantly larger than those of pelagic nets (depth $>3 \mathrm{~m}$ ), $5.7 \mathrm{~kg}$ and $2.3 \mathrm{~kg}$, respectively (Table 1). Consequently, catches of almost all species were significantly larger in littoral nets. Ruffe catches were similar in littoral and pelagic nets and smelt was the only completely pelagic species (Table 1).

The mean WM of fish in the total gillnet catches fluctuated irregularly and so did the mean WM of perch, pikeperch and bream. The mean WM of rudd, white bream, bleak and smelt increased whereas that of ruffe and roach decreased (Fig. 4). Statistically significant increasing trend for white bream $\left(r^{2}=0.69, P<0.001\right)$ and significant decreasing trend for ruffe $\left(r^{2}=0.67, P<0.001\right)$ is expressed as grey line in Fig. 4b, c, respectively.

Hydroacoustic assessment of fish biomass

Unlike gillnet monitoring which covered the whole lake area, results of late autumn pelagic echosounding suggested decreasing pelagic fish biomasses during 1997-1999 (Fig. 5) coinciding with the high mass and Crucian carp (Carassius carassius L.). In addition, some individuals of introduced species whitefish (Coregonus lavaretus L.), asp (Aspius aspius L.) and common carp (Cyprinus carpio L.) were caught

removals of fish in those years. In years with the total biomass estimates of $200-300 \mathrm{~kg} \mathrm{ha}^{-1}$ at the highest, smelt was the most abundant species in the pelagic zone by biomass until there was a clear collapse of the stock in 2002 (Fig. 6, Malinen, 2017), apparently due to unfavorable thermal conditions. Thereafter, total fish biomass estimates in August-September varied between 65 and $150 \mathrm{~kg} \mathrm{ha}^{-1}$ and showed no clear trend (Fig. 6). During 2004-2018, bream was the most abundant species by biomass in seven years with a mean proportion of $27 \%$ followed by smelt, pikeperch, white bream, perch and roach $(8-16 \%)$. In the latest years of the study a clear recovery of the smelt stock took place up to a contribution of $40 \%$ of the total fish biomass. In terms of densities, the most abundant species throughout the study period were smelt, $0+$ pikeperch and small Abramis sp. (small abramis = sum of bream and white bream of $<80 \mathrm{~mm}$ total length, Malinen et al., 2017). A positive $\left(r^{2}=0.30\right)$ but non-significant relation was found between the hydroacoustic total fish biomass estimates and total BPUE from NORDIC nets in the pelagic zone. At the species level, significant relations were found for smelt and perch (Fig. 7). 


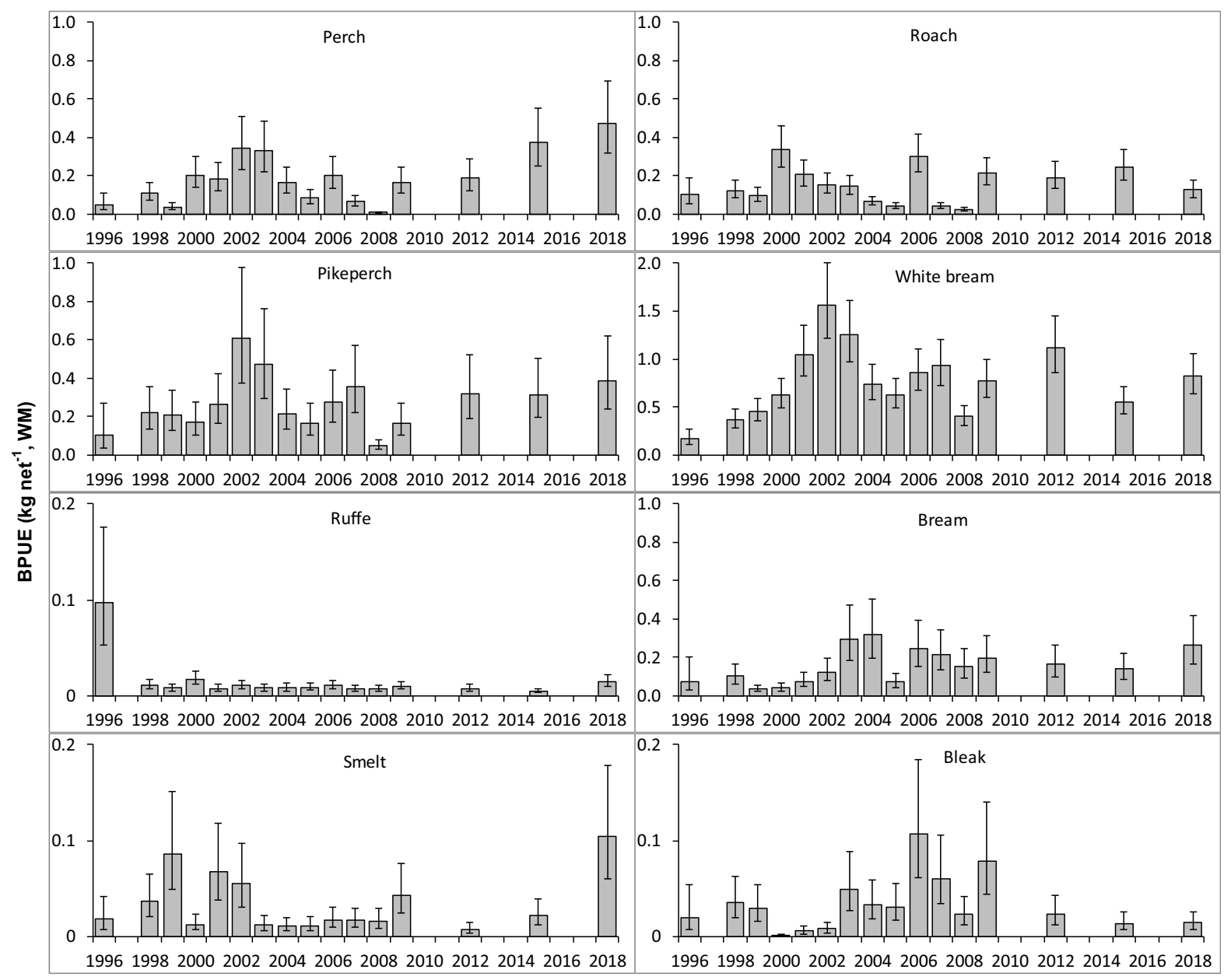

Fig. 3 BPUE (geometric mean $+95 \%$ confidence limits) of eight fish species from NORDIC gillnet catches during 1996-2018

Table 1 Total and speciesspecific average BPUE $(\mathrm{kg}$ fish per gillnet night, WM) in the littoral $(<3 \mathrm{~m})$ and pelagic ( $>3 \mathrm{~m}$ ) gillnets; $P$ : $P$ values of generalized mixed linear model tests

\begin{tabular}{llclcr}
\hline Species & Littoral & $95 \%$ conf. limits & Pelagial & $95 \%$ conf. limits & $P$ \\
\hline Total & 5.7 & $5.3-6.1$ & 2.2 & $2.1-2.4$ & $<0.001$ \\
Perch & 0.60 & $0.51-0.71$ & 0.19 & $0.16-0.22$ & $<0.001$ \\
Pikeperch & 0.44 & $0.39-0.51$ & 0.33 & $0.28-0.38$ & 0.004 \\
Ruffe & 0.049 & $0.041-0.059$ & 0.047 & $0.038-0.057$ & 0.609 \\
Smelt & 0.001 & $0.001-0.002$ & 0.068 & $0.055-0.085$ & $<0.001$ \\
Roach & 2.1 & $1.8-2.5$ & 0.25 & $0.21-0.30$ & $<0.001$ \\
White bream & 1.3 & $1.2-1.5$ & 0.78 & $0.70-0.87$ & $<0.001$ \\
Bream & 0.42 & $0.35-0.50$ & 0.15 & $0.12-0.18$ & $<0.001$ \\
Rudd & 0.16 & $0.11-0.24$ & 0.10 & $0.063-0.47$ & 0.002 \\
Bleak & 0.083 & $0.067-0.10$ & 0.061 & $0.048-0.077$ & 0.017 \\
\hline
\end{tabular}



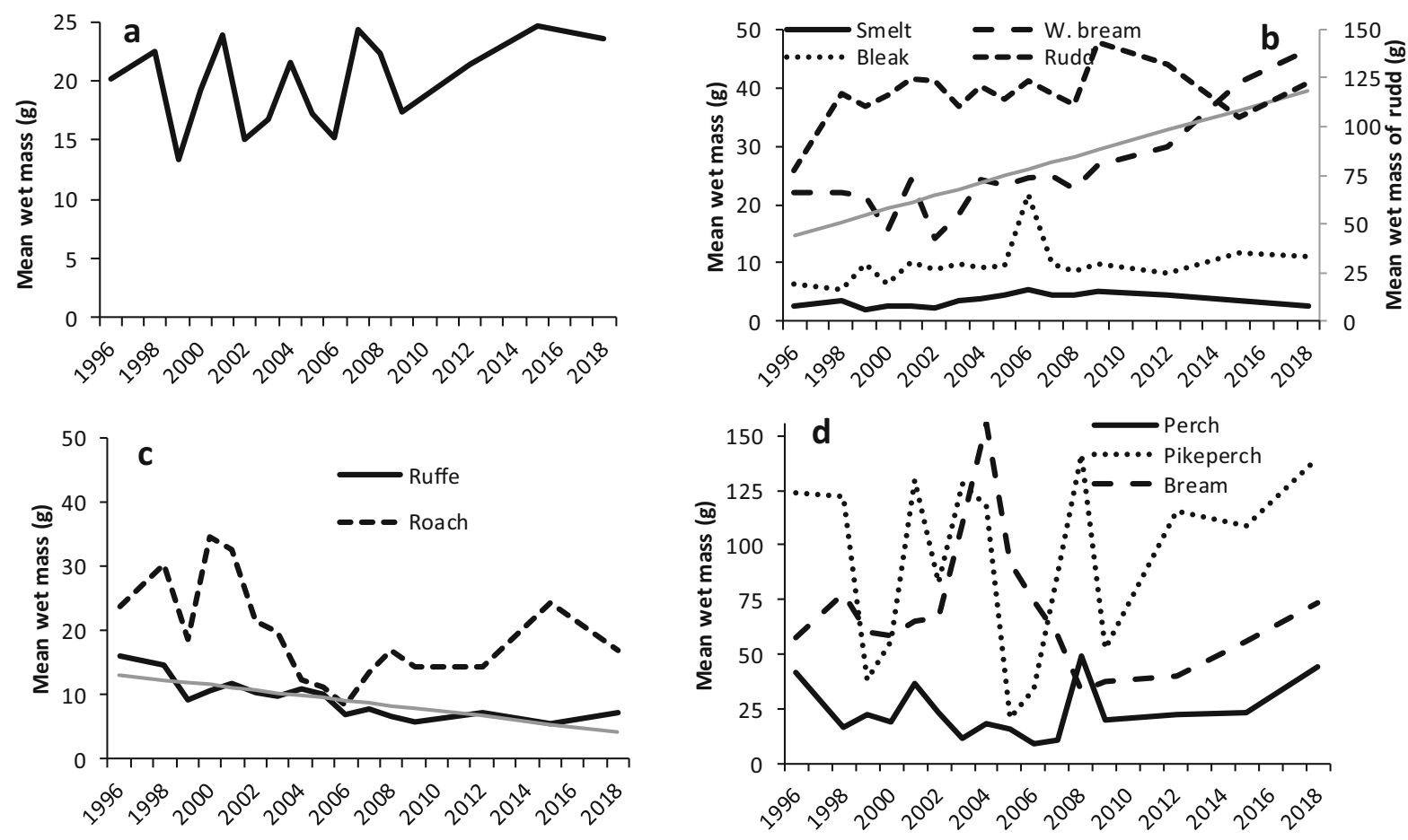

Fig. 4 Average wet mass in the total catch (a), and for species with mean wet mass increasing (b), decreasing (c) or having no trend (d). Note that there were no observations from year 1997, 2010, 2011, 2013, 2014, 2016 and 2017

Fig. 5 Hydroacoustic fish biomass estimates in $>5-\mathrm{m}$ deep areas of Lake Tuusulanjärvi during 1997-2018. Vertical bars indicate the $95 \%$ confidence limits

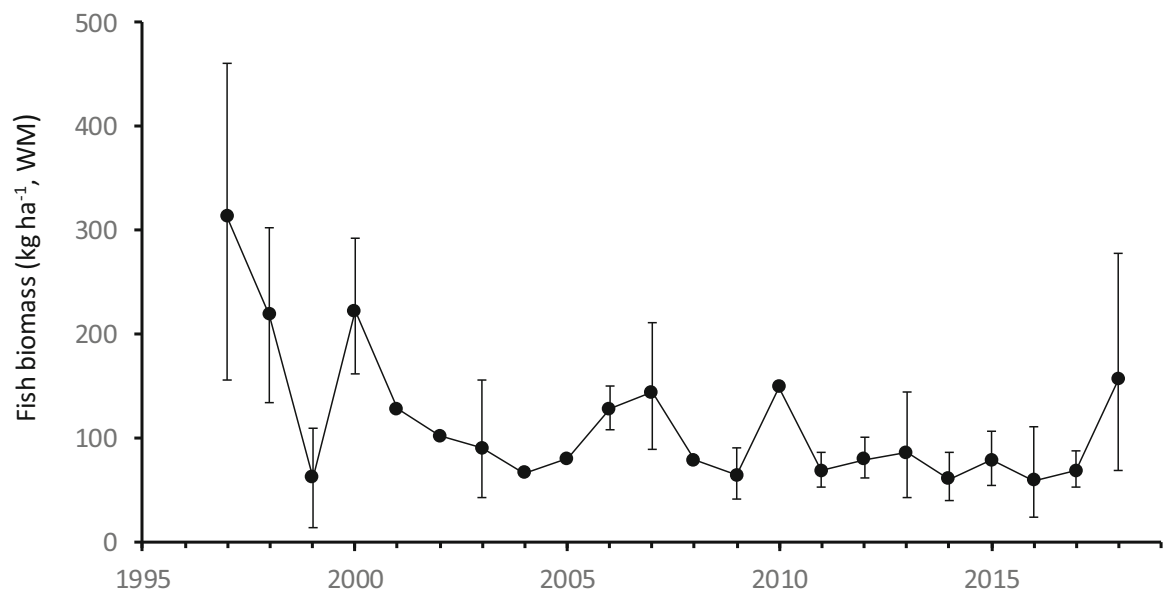

VPA estimates for the dominant cyprinids

VPA estimates for the three most abundant cyprinid species suggested increasing population biomass estimates for bream and white bream during 2005-2011 (Fig. 8). The estimated increase for the bream stock was from $14,000 \mathrm{~kg}\left(24 \mathrm{~kg} \mathrm{ha}^{-1}, \mathrm{WM}\right)$ in 2005 up to $65,000 \mathrm{~kg}\left(110 \mathrm{~kg} \mathrm{ha}^{-1}, \mathrm{WM}\right)$ in 2011, and for white bream from $14,000 \mathrm{~kg}$ to $33,000 \mathrm{~kg}\left(55 \mathrm{~kg} \mathrm{ha}^{-1}\right.$,
WM) during the same period. The roach biomass estimates fluctuated in these years between 16,000 and $29,000 \mathrm{~kg}$ (27-49 $\mathrm{kg} \mathrm{ha}^{-1}$, WM). The total biomass of these three species according to the VPA calculations was $80-200 \mathrm{~kg} \mathrm{ha}^{-1}$ during 2005-2011, which clearly exceeded the hydroacoustic biomass estimates for the pelagic ( $>5 \mathrm{~m}$ deep) area. By the autumn seining, $11-37 \%$ of bream biomass, $6-22 \%$ of white 


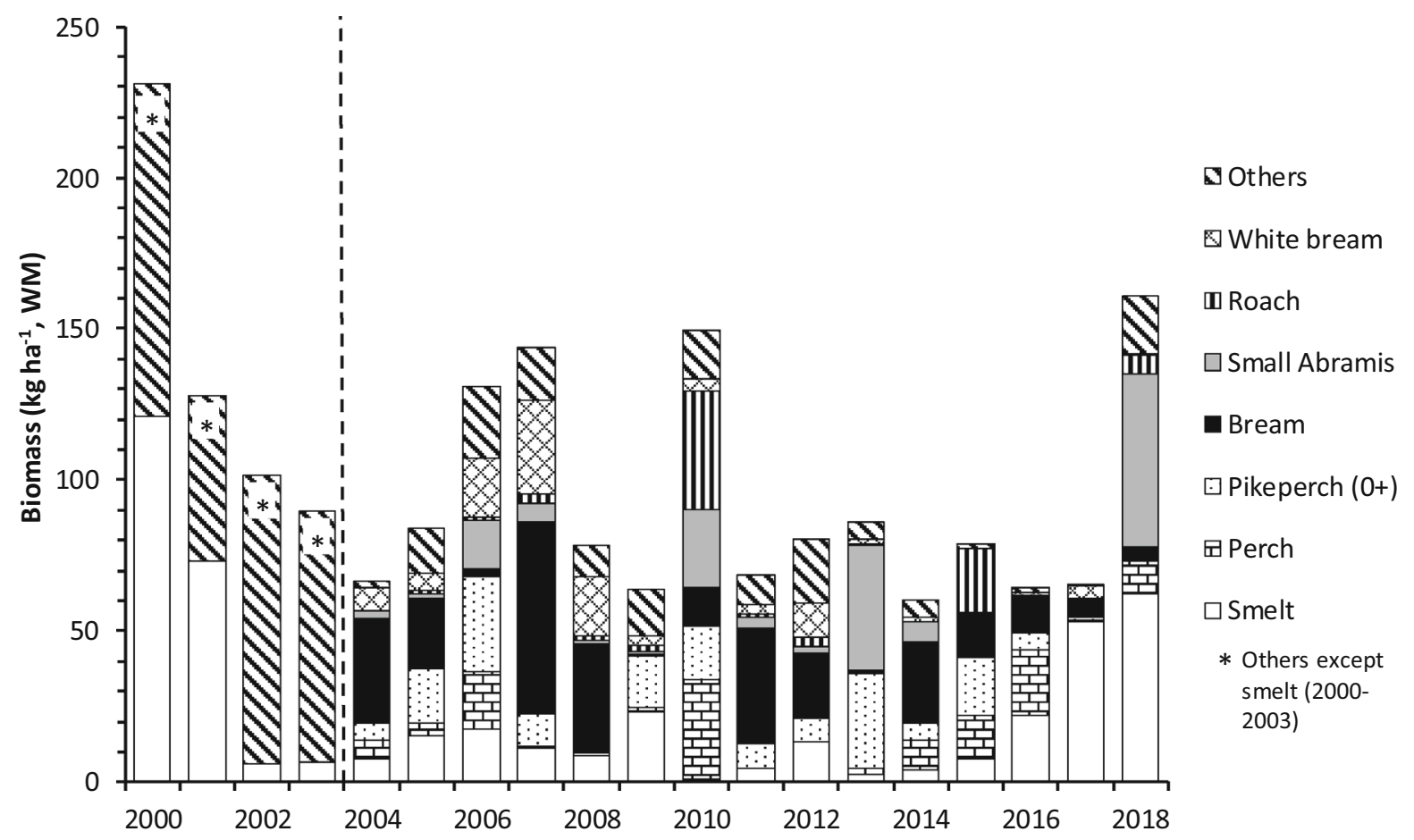

Fig. 6 Hydroacoustic fish biomass estimates in $>5 \mathrm{~m}$ deep areas of Lake Tuusulanjärvi during 2000-2018. In the years 2000-2003, the category Others included all species except

bream and 3-63\% of roach was removed in these years.

\section{Growth of fish}

The first year growth of roach, bream, perch and pikeperch born after the onset of the restoration was slightly faster than growth of those born before the project. Coinciding with the start of the mass removal, the growth rates of older than one-year fish increased (though not significantly for pikeperch), while the growth of bream showed the most striking increase (Fig. 9).

\section{Discussion}

In the first years of biomanipulation, the target removal catch $200 \mathrm{~kg} \mathrm{ha}^{-1}$ in three years was reached. Consequently, late autumn hydroacoustic fish biomass estimates indicated clear reduction in pelagic fish abundance but the total gillnet BPUE increased unexpectedly from 1996 to 2002. The temporal smelt. In the years 2004 to 2018 the category others comprised mainly of rudd, bleak, ruffe and eel (Anguilla anguilla L.)

decreases of gillnet BPUE of bream, bleak, ruffe and smelt in the same time reflected their efficient removal in the early years of the food web management. Removal catches of bream totalling more than $100 \mathrm{~kg} \mathrm{ha}^{-1}$ in 1997-1999 appeared sufficient to temporarily decrease the gillnet BPUE of bream while a $50 \mathrm{~kg} \mathrm{ha}^{-1}$ removal catch of bleak in the same years (Sammalkorpi, 2000) decreased the bleak catches. The increase of the BPUE of bream and bleak until 2003 and generally high gillnet catches in the course of the project since then suggest insufficient efficiency of the biomanipulation during 2000s.

An apparent explanation for the increased gillnet BPUE after onset of the removal fishing was the dramatic increase in reproduction efficiency of the remaining fish (Hansson et al., 1998; Olin et al., 2006) accompanied by increased growth rates of fish (Rask et al., 2005), especially for bream. In an extensive Finnish biomanipulation study increased YOY fish production or effective biomass compensation by cyprinids were recorded in 10 out of 14 eutrophicated lake ecosystems (Olin et al., 2006). Furthermore, following an almost complete fish kill in a eutrophic 

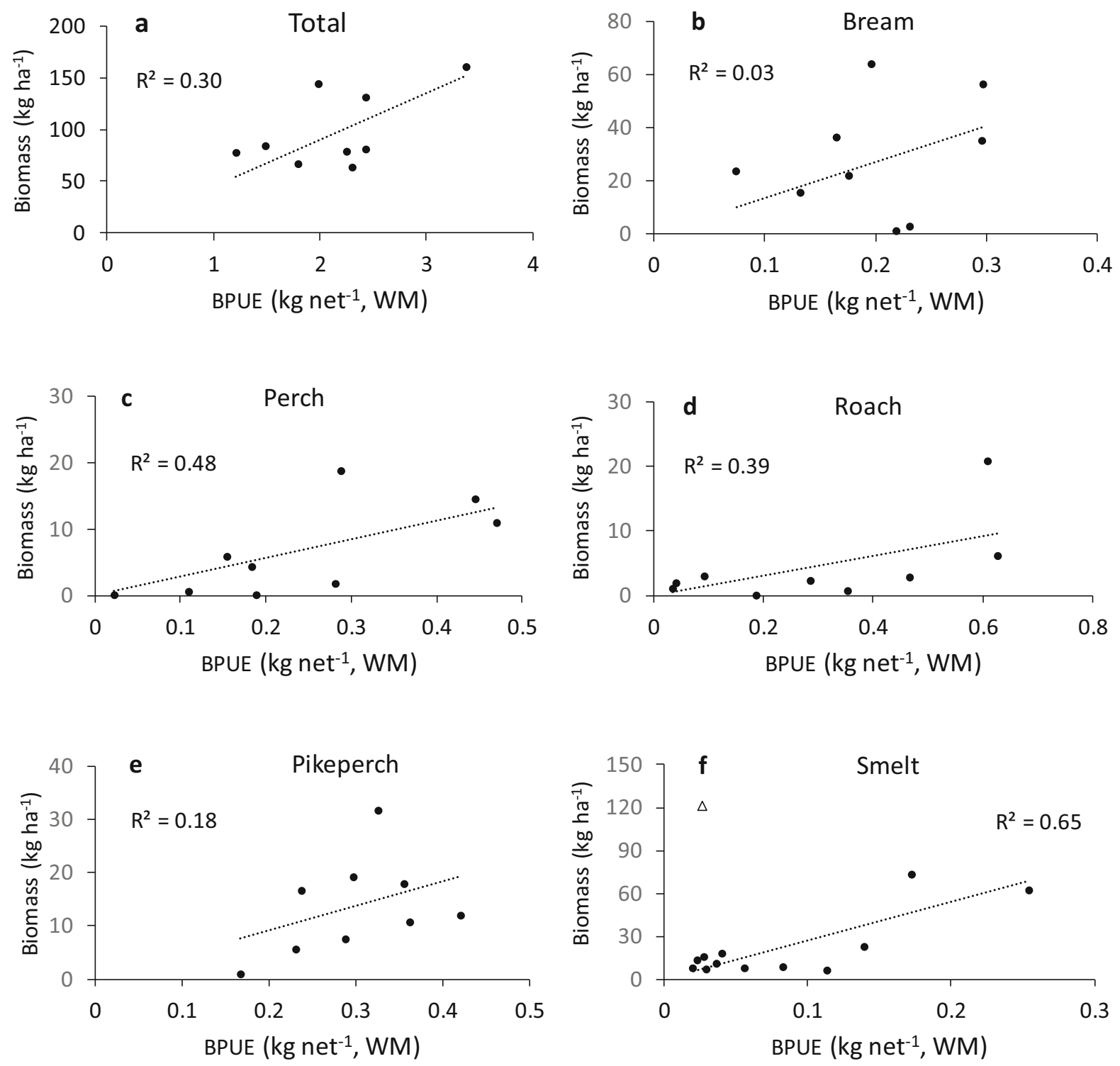

Fig. 7 Hydroacoustic-based total biomass estimates and estimates of key species in the pelagic zone of Lake Tuusulanjärvi since 2004 related to the mean gillnet BPUE values of pelagic

lake the effective reproduction of the remaining fish resulted in an equal gillnet BPUE in the next summer compared to the earlier years (Ruuhijärvi et al., 2010).

It is likely that the collapse of smelt in the early 2000s, seen in both the gillnet BPUE and the hydroacoustic estimates, was a consequence of unfavorable environmental conditions induced by the warm summer of 2002 and the absence of cool metalimnetic water due to the hypolimnetic aeration breaking down the thermal stratification of the lake.

nets (those held in depth zones $>3 \mathrm{~m}$ ). For smelt data from years 2000-2003 were added. An outlier (year 2000) indicated with a triangle

Identical collapses of smelt stocks were documented in the same year in two other lakes in Finland (Ruuhijärvi et al., 2005; Keskinen et al., 2012). The appearance of the exceptionally large year-class of smelt in 2017 may have been promoted by the cool summer that contributed to the relatively low water temperatures optimal for the $0+$ smelt.

Generally, the regular occurrence of pikeperch in the gillnet catches with BPUE $0.2-0.6 \mathrm{~kg}$, higher (though not significantly) growth rate and high 

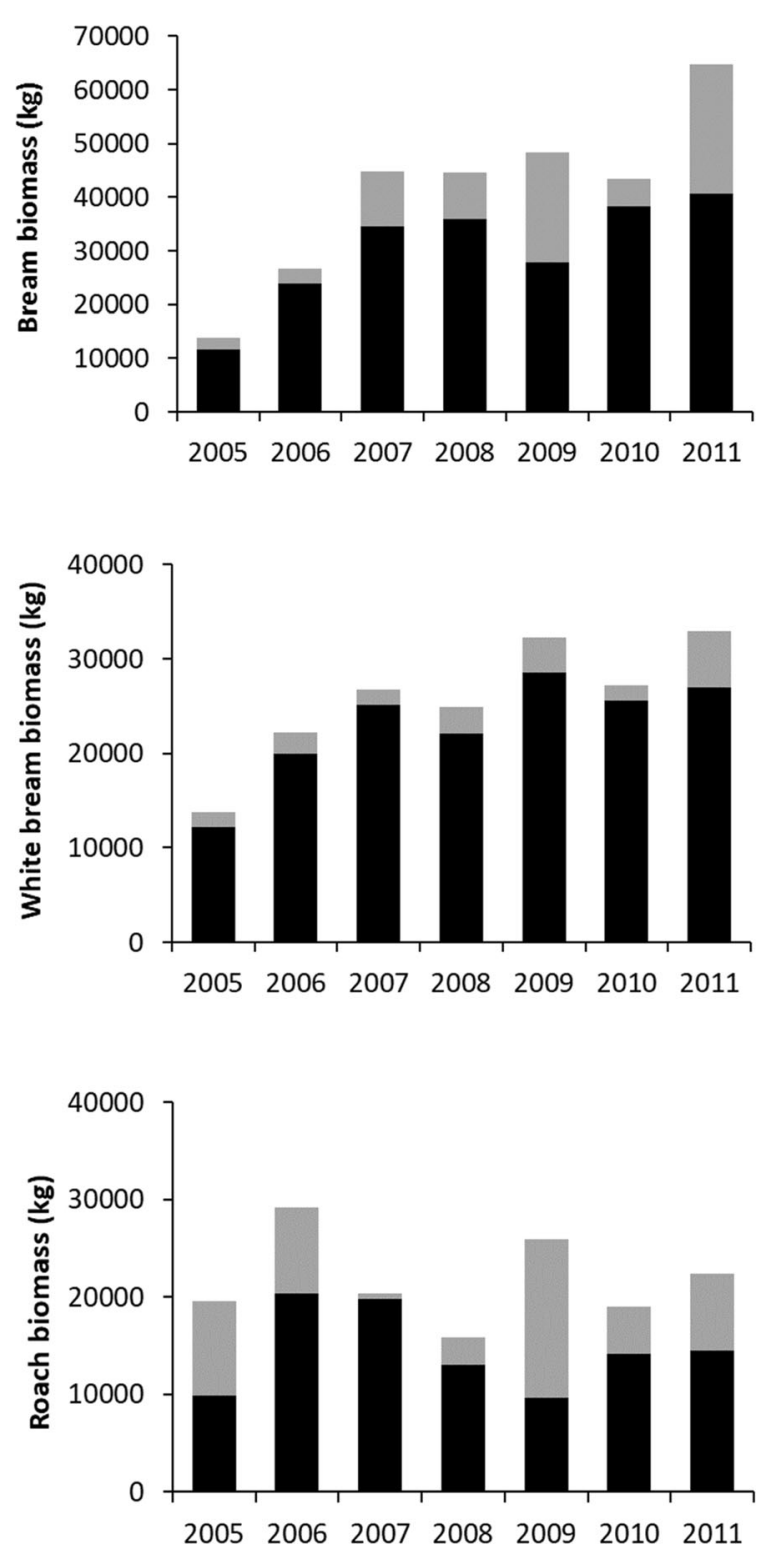

Fig. 8 Total biomasses of bream, white bream and roach in Lake Tuusulanjärvi during 2005-2011 calculated with VPA (cohort analysis). Grey section of bars indicates the proportion of the biomass removed by autumn seining each year

hydroacoustic biomasses of $0+$ pikeperch (Malinen, 2017) throughout the research period of two decades all indicate a good status of pikeperch in Lake Tuusulanjärvi. This is noticeable, as pikeperch is the most important target species of recreational fishing in the lake and certainly affects the acceptability of the restoration project among local residents. Actually, the management fishing induced an increase in the abundance of small individuals of several prey fish species in the lake which has probably benefitted the pikeperch population.

The proportion of predatory fish in the gill net catches of Lake Tuusulanjärvi (10-18\% throughout the study period) apparently remained too low for predatory control of planktivorous fish (Jeppesen et al., 1990). There are examples of biomanipulations with fish community shifts towards more piscivorous direction in lakes with levels of eutrophication similar to Lake Tuusulanjärvi (Reinertsen et al., 1990; Søndergaard et al., 1990). As no statistics of the catches of recreational fishermen are available, the potential impact of fishing on the development of the fish community of Lake Tuusulanjärvi cannot be estimated. According to irregular interviews by KUVES, the fishermen often have experienced biomanipulation as a positive activity.

According to European studies, removals of 50 to $75 \%$ of planktivorous fish biomass are needed for successful biomanipulations (Meijer et al., 1999; Søndergaard et al., 2007; Bernes et al., 2015). Such removals were not reached in Lake Tuusulanjärvi. In addition, the wide year-to-year variation in the mass removal catches apparently decreased the efficiency of biomanipulation. As calculated on the basis of the VPA analyses for bream, white bream and roach that annually made $53-86 \%$ of removed fish biomass in Lake Tuusulanjärvi, the mean annual proportion of removed biomass from the stock varied between 12 and $32 \%$ depending on the species. In addition to the efficiency of fish removal, several other factors can affect the success in lake biomanipulation. These include clay and humic turbidity, wind resuspension, lake area and depth, high nutrient concentrations due to insufficient external loading reduction or internal loading and absence of stable submerged macrophyte communities, high density of cyanobacteria and presence of invertebrate predators (Jeppesen et al., 1990; Meijer et al., 1999; Søndergaard et al., 2007; Gulati et al., 2008). In Tuusulanjärvi clay turbidity is limiting the possibilities of aquatic macrophytes to expand their distribution and stabilize the sediment. It also affects the schooling behavior of cyprinid fishes, essential for successful fish removal (Sammalkorpi, 2000) and decreases the predation efficiency of visually hunting fish such as perch and pike (Diehl, 1988; Olin et al., 2006). Further, the external phosphorus load to the lake still exceeds the annual 
Fig. 9 Total length (mean $\pm \mathrm{SD}$ ) of one-yearold roach, bream, perch and pikeperch in Lake Tuusulanjärvi (a) and annual length increment (mean $\pm \mathrm{SD}$ ) of the same species in older ages (b). Black bars indicate fish born before the management fishing and gray bars those born after the onset of fishing
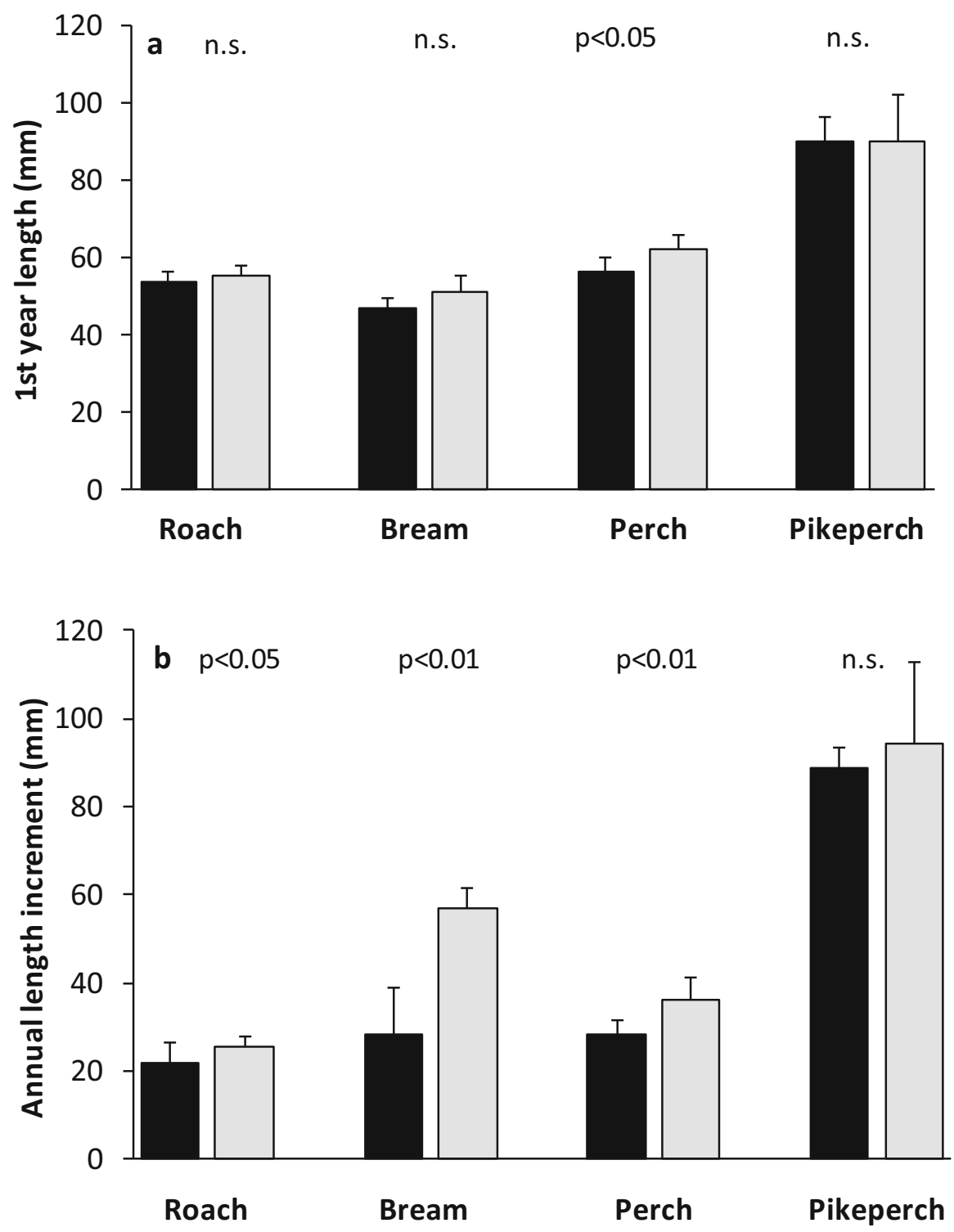

phosphorus loss from the lake in most years and internal nutrient load is also remarkable (Luodeslampi et al., 2017). However, assuming a $0.8 \%$ phosphorus proportion from the fresh mass of cyprinid fish (Schreckenbach et al., 2001), 0.2-1.4 $\mathrm{kg} \mathrm{ha}^{-1}$ of P was removed annually in the biomanipulation of Lake Tuusulanjärvi (Luodeslampi et al., 2017). This is $3-40 \%$ of the annual total $\mathrm{P}$ losses from the lake, highest proportions in dry years with low total $\mathrm{P}$ load and lowest proportions in rainy years of highest $\mathrm{P}$ load to the lake (See also Pedusaar et al., 2010). Together with other restoration activities of the project, this has probably made a beneficial contribution to the general positive development of the lake.

Despite certain shortcomings such as wide random variation in BPUEs, and underestimation of the abundance of some species such as bream, smelt, and generally small $(<10 \mathrm{~cm})$ fish (Olin \& Malinen, 2003; Olin et al., 2009), NORDIC gill netting is considered a useful tool for producing index-type information on the status of fish community, as well on the effects of natural variability as of fish stock manipulations. This view is supported by the significant correlations between pelagic gillnet BPUEs and 
hydroacoustic biomass estimates for perch and smelt in the present study. In an earlier study Peltonen et al. (1999b) reported that gillnet CPUE was not suitable for analysing the dynamics of smelt stocks. The difference in the findings of the two studies is mainly that NORDIC survey nets contain small mesh sizes (5, $6.25,8$ and $10 \mathrm{~mm}$ ) and thus have higher catching efficiency for small fish like smelt compared to the nets used in the study of Peltonen et al. (1999b). In Lake Tuusulanjärvi, where the abundance of fish is high, a decrease of gillnet catchability due to fish accumulation to nets may also affect the catching efficiency (Olin et al., 2004). This may have leveled off the highest gillnet catches in the present study. Moreover, year-to-year variations in water temperature and water turbidity affect gillnet catches (Olin et al., 2006).

Echo sounding and experimental trawling are useful methods for assessing pelagic fish abundance, especially of smelt, $0+$ pikeperch and small $(<8 \mathrm{~cm})$ bream and white bream that largely remain underestimated in gillnet catches. However, hydroacoustics are not recommended for larger cyprinids due to their intermittent tendency to occupy shallow areas and the bottom dead zone of the echo sounder, which leads to high variation in estimates and also accounts for the smaller biomass estimates of bream, white bream and roach compared to those obtained from VPA calculations in 2005-2011. The biomass increase of bream and white bream recorded in VPA analyses may have been a consequence of low seining catches in 2005 and 2006. The roach biomass estimates fluctuated in these years between 15 and 30 tons suggesting that the removal catches of roach, more than $50 \%$ of the stock biomass in the best years, were high enough to prevent the increase in biomass.

In Lake Tuusulanjärvi, the high variation in the catchabilities of bream and white bream are likely to decrease the quality of the VPA estimates. This is due to the high between-year variation in advancement of the autumn, which affects the fish behavior, and more specifically, the occurrence of large schools which are optimal targets for effective seine fishing (Sammalkorpi, 2000). However, variations in catchability particularly influence VPA estimates close to the end of the analysed time period while the estimates for the earlier years of the study period are more accurate. In spite of these evident weaknesses, VPA was found to be a valuable supplement for monitoring the responses of fish stocks in Lake Tuusulanjärvi. This study suggests that it was the most suitable of the methods for bream stock monitoring, and it revealed the clear dominance of bream compared with other cyprinid species.

\section{Concluding remarks}

The mass removal of planktivorous cyprinids from Lake Tuusulanjärvi over two decades did not result in long-term changes in fish abundance and species relations. Despite reaching the target catch of the fish removal in the first years of the project and consequent promising signs in responses, the efficiency of the biomanipulation remained too low in later years of the study period.

In spite of successful long-term activities to reduce nutrient loads to the lake, the phosphorus level is still high enough to allow high overall productivity of the ecosystem. Consequently, fish production was high enough to compensate the removals by effective reproduction and growth. Further, clay turbidity in rainy years decreased the schooling of cyprinid fish in the lake limiting the possibilities of effective fish removal and the predation effect of visually hunting piscivores.

Despite the lack of long-standing changes in fish abundance and community structure in Lake Tuusulanjärvi, the amount of nutrients removed in fish and those bound to fish biomass due to increased growth of fish probably have contributed to the positive development of the lake as indicated, for example, in decreased algal blooms during the study period.

In lakes such as Tuusulanjärvi with distinct littoral and pelagic habitats, a combination of gillnet monitoring and hydroacoustics is optimal for assessing the fish community responses to food web manipulation. However, for lakes with an abundant bream stock, these methods should be supplemented with catchesat-age methods such as VPA. It is essential to apply fish stock assessment, preferably using more than just one method, to acquire information about the dynamics of fish stocks providing management guidance in lake restoration projects, in particular if fishing is among the management tools.

Acknowledgements Open access funding provided by University of Helsinki including Helsinki University Central Hospital is acknowledged. This study was funded by the 
University of Helsinki, Natural Resources Institute Finland (formerly Finnish Game and Fisheries Research Institute), Finnish Environment Institute and Mid-Uusimaa Board for Water Protection Control as a part of their joint research projects on restoration of eutrophicated lakes. Professor Roger I. Jones kindly checked the English language.

Open Access This article is licensed under a Creative Commons Attribution 4.0 International License, which permits use, sharing, adaptation, distribution and reproduction in any medium or format, as long as you give appropriate credit to the original author(s) and the source, provide a link to the Creative Commons licence, and indicate if changes were made. The images or other third party material in this article are included in the article's Creative Commons licence, unless indicated otherwise in a credit line to the material. If material is not included in the article's Creative Commons licence and your intended use is not permitted by statutory regulation or exceeds the permitted use, you will need to obtain permission directly from the copyright holder. To view a copy of this licence, visit http://creativecommons.org/licenses/by/4.0/.

\section{References}

Appelberg, M., H. M. Berger, T. Hesthagen, E. Kleiven, M. Kurkilahti, J. Raitaniemi \& M. Rask, 1995. Development and intercalibration of methods in nordic freshwater fish monitoring. Water Air Soil Pollution 85: 401-406.

Bagenal, T. B. \& F. W. Tesch, 1978. Age and growth. In Bagenal, T. (ed.), Methods for Assessment of Fish Production in Fresh Waters. Blackwell, Oxford: 101-136.

Benndorf, J., 1990. Conditions for effective biomanipulation: conclusions derived from whole-lake experiments in Europe. Hydrobiologia 200(201): 187-203.

Bernes, C., S. R. Carpenter, A. Gårdmark, P. Larsson, L. Persson, C. Skov, J. D. M. Speed \& E. Van Donk, 2015. What is the influence of a reduction of planktivorous and benthivorous fish on water quality in temperate eutrophic lakes? A systematic review. Environmental Evidence 4: 7.

Carpenter, S. R., J. F. Kitchell \& J. R. Hodgson, 1985. Cascading trophic interactions and lake productivity. BioScience 35: 634-639.

CEN, 2005. Water quality - sampling fish with multi-mesh gillnets. European standard EN 14757:2005: 27p.

Diehl, S., 1988. Foraging efficiency of three freshwater fishes: effects of structural complexity and light. Oikos 53: 207-214.

Gulati, R. D., L. M. D. Pires \& E. Van Donk, 2008. Lake restoration studies: failures, bottlenecks and prospects of new ecotechnological measures. Limnologica 38 : 233-247.

Hansson, L.-A., H. Annadotter, E. Bergman, S. F. Hamrin, E. Jeppesen, T. Kairesalo, E. Luokkanen, P. A. Nilsson \& M. Søndergaard, 1998. Biomanipulation as an application of food chain theory: constraints, synthesis and recommendations for temperate lakes. Ecosystems 1: 558-574.

Hietala, J. \& M. Pekkarinen, 2017. Tuusulanjärven hoitotoimet ja tilan kehitys (Restoration activities and progress in the status of Lake Tuusulanjärvi). Uusimaa Centre for Economic Development, Transport and the Environment. Report 56/2017: 7-11 (In Finnish).

Horppila, J. \& K. Nyberg, 1999. The validity of different methods in the back-calculation of the lengths of roach - a comparison between scales and cleithra. Journal of Fish Biology 54: 489-498.

Horppila, J. \& H. Peltonen, 1994. The fate of a roach Rutilus rutilus stock under an extremely strong fishing pressure and its predicted development after the cessation of mass removal. Journal of Fish Biology 45: 777-786.

Horppila, J., H. Peltonen, T. Malinen, E. Luokkanen \& T. Kairesalo, 1998. Top-down or bottom-up effects by fish: issues of concern in biomanipulation of lakes. Restoration Ecology 6: 20-28.

Järnefelt, H., 1937. Ein kleiner Beitrag zur Limnologie des Tuusulanjärvi (Tuusulasee). Acta Societas pro fauna et flora Fennica 60: 502-515.

Järvinen, M. \& L. Lepistö, 2017. Tuusulanjärven kasviplankton vuosina 1961-2012 (The phytoplankton in Lake Tuusulanjärvi during 1961-2012). Uusimaa Centre for Economic Development, Transport and the Environment. Report 56/2017: 39-44 (In Finnish).

Jeppesen, E., J. P. Jensen, P. Kristensen, M. Søndergaard, E. Mortensen, O. Sortkjaer \& K. Olrik, 1990. Fish mainpulation as a lake restoration tool in shallow, eutrophic, temperate lakes 2: threshold levels, long-term stability and conclusions. Hydrobiologia 200(201): 219-227.

Jolly, G. M. \& I. Hampton, 1990. Some problems in the statistical design and analysis of acoustic surveys to assess fish biomass. Rapports et procès-verbaux des réunions Conseil International pour l'Exploration de la Mer 189: 415-420.

Keskinen, T., J. Lilja, P. Högmander, J. A. Holmes, J. Karjalainen \& T. Marjomäki, 2012. Collapse and recovery of the European smelt (Osmerus eperlanus) population in a small boreal lake - an early warning of the consequences of climate change. Boreal Environment Research 17: 398-410.

Luodeslampi, P., J. Marttila \& J. Hietala, 2017. Tuusulanjärven vesitase ja ravinnetaseet vuosina 1990-2013 (Water and nutrient balance in Lake Tuusulanjärvi during 1990-2013). Uusimaa Centre for Economic Development, Transport and the Environment. Report 56/2017: 13-19 (In Finnish).

MacLennan, D. N., P. G. Fernandes \& J. Dalen, 2002. A consistent approach to definitions and symbols in fisheries acoustics. ICES Journal of Marine Sciience 59: 365-369.

Malinen, T., 2017. Tuusulanjärven ulappa-alueen kalasto vuosina 1997-2013 kaikuluotauksen ja koetroolauksen perusteella arvioituna (Pelagic fish community in Lake Tuusulanjärvi during 1997-2013 assessed by means of echo sounding and experimental trawling). Uusimaa Centre for Economic Development, Transport and the Environment. Report 56/2017: 62-70 (In Finnish).

Malinen, T., J. Kervinen \& H. Peltonen, 2017. Tuusulanjärven lahna-, pasuri-, ja särkikannat vuosina 2005-2011 (Bream, white bream and roach stocks in Lake Tuusulanjärvi during 2005-2011). Uusimaa Centre for Economic Development, Transport and the Environment. Report 56/2017: 51-60 (In Finnish).

Malinen, T., 2018. Hydroacoustic fish stock assessment in southern and northern boreal lakes - potential and 
constraints. PhD dissertation. Faculty of Biological and Environmental Sciences, University of Helsinki. Hansaprint Oy, Turenki. 62 pp.

McCullagh, P. \& J. A. Nelder, 1989. Generalized Linear Models, 2nd ed. Chapman \& Hall, London.

Meijer, M. L., I. de Bois, M. Scheffer, R. Portielje \& H. Hosper, 1999. Biomanipulation in the shallow lakes in The Netherlands: an evaluation of 18 case studies. Hydrobiologia 408(409): 13-30.

Olin, M. \& T. Malinen, 2003. Comparison of gillnet and trawl in diurnal fish community sampling. Hydrobiologia 506-509: 443-449.

Olin, M., M. Kurkilahti, P. Peitola \& J. Ruuhijärvi, 2004. The effects of fish accumulation on the catchability of multimesh gillnet. Fisheries Research 68: 135-147.

Olin, M., M. Rask, J. Ruuhijärvi, J. Keskitalo, J. Horppila, P. Tallberg, T. Taponen, A. Lehtovaara \& I. Sammalkorpi, 2006. Effects of biomanipulation on plankton and fish communities in ten eutrophic lakes in southern Finland. Hydrobiologia 553: 67-88.

Olin, M., T. Malinen \& J. Ruuhijärvi, 2009. Gillnet catch in estimating the density and structure of fish community comparison of gillnet and trawl samples in a eutrophic lake. Fisheries Research 96: 88-94.

Pedusaar, T., I. Sammalkorpi, A. Hautala, J. Salujoe, A. Järvalt \& M. Pihlak, 2010. Shifts in water quality in a drinking water reservoir during and after the removal of cyprinids. Hydrobiologia 679: 95-106.

Pekkarinen, M., 1990. Comprehensive survey of the hypertrophic Lake Tuusulanjärvi, nutrient loading, water quality and prospects of restoration. Aqua Fennica 20: 13-25.

Peltonen, H., J. Ruuhijärvi, T. Malinen, J. Horppila, M. Olin \& J. Keto, 1999a. The effects of food-web management on fish assemblage dynamics in a north temperate lake. Journal of Fish Biology 55: 54-67.

Peltonen, H., J. Ruuhijärvi, T. Malinen \& J. Horppila, 1999b. Estimation of roach (Rutilus rutilus (L.)) and smelt (Osmerus eperlanus (L.)) stocks with virtual population analysis, hydroacoustics and gillnet CPUE. Fisheries Research 44: 25-36.

Peltonen, H., T. Malinen \& A. Tuomaala, 2006. Hydroacoustic in situ target strength of smelt (Osmerus eperlanus (L.)). Fisheries Research 80: 190-195.

Pope, J. G., 1972. An investigation of the accuracy of virtual population analysis using cohort analysis. ICNAF Research Bulletin 9: 65-74.

Raitaniemi, J., M. Rask \& P. J. Vuorinen, 1988. The growth of perch, Perca fluviatilis L., in small Finnish lakes at different stages of acidification. Annales Zoologici Fennici 25: 209-219.

Rask, M., J. Ruuhijärvi, M. Olin, A. Lehtovaara, S. Vesala \& I. Sammalkorpi, 2005. Responses of zooplankton and fish to restoration in eutrophic Lake Tuusulanjärvi, in southern Finland. Verhandlungen des Internationalen Verein Limnologie 29: 545-549.
Reinertsen, H., A. Jensen, J. I. Koksvik, A. Langeland \& Y. Olsen, 1990. Effects of fish removal on the limnetic ecosystem of a eutrophic lake. Canadian Journal of Fisheries and Aquatic Sciences 47: 166-173.

Ricker, W. E., 1975. Computation and interpretation of biological statistics of fish populations. Fisheries Research Board of Canada, Bulletin 191: 1-382p.

Ruuhijärvi, J., M. Salminen \& T. Nurmio, 1996. Releases of pikeperch (Stizostedion lucioperca L.) finerlings in lakes with no established pikeperch stock. Annales Zoologici Fennici 33: 553-567.

Ruuhijärvi, J., T. Malinen, P. Ala-Opas \& A. Tuomaala, 2005. Fish stocks of Lake Vesijärvi: from nuisance to flourishing fishery in 15 years. Verhandlungen des Internationalen Verein Limnologie 29: 384-389.

Ruuhijärvi, J., M. Rask, S. Vesala, A. Westermark, M. Olin, J. Keskitalo \& A. Lehtovaara, 2010. Recovery of the fish community and changes in the lower trophic levels in a eutrophic lake after a winterkill of fish. Hydrobiologia 646: 145-158.

Saarijärvi, E. \& K.-M. Lappalainen, 2004. Regulation of stratification as a tool for improving oxygen state. Verhandlungen des Internationalen Verein Limnologie 29: 1037-1042.

Sammalkorpi, I., 2000. The role of fish behavior in biomanipulation of a hypertrophic lake. Verhandlungen des Internationalen Verein Limnologie 27: 1464-1472.

Sarvala, J., A.-M. Ventelä, H. Helminen, A. Hirvonen, V. Saarikari, S. Salonen, A. Sydänoja \& K. Vuorio, 2000. Restoration of the eutrophicated Köyliönjärvi (SW Finland) through fish removal: whole-lake vs. mescosm experiences. Boreal Environment Research 5: 39-52.

Schreckenbach, K. R., R. Knösche \& K. Ebert, 2001. Nutrient and energy content of freshwater fishes. Journal of Applied Ecology 17: 142-144.

Shotton, R. \& G. P. Bazigos, 1984. Techniques and considerations in the design of acoustic surveys. Rapports et procèsverbaux des réunions Conseil International pour 1'Exploration de la Mer 184: 34-57.

Simmonds, J. \& D. MacLennan, 2005. Fisheries Acoustics: Theory and Practice. Blackwell Science, Oxford.

Søndergaard, M., E. Jeppesen, E. Mortensen, E. Dall, P. Kristensen \& O. Sortkjaer, 1990. Phytoplankton biomass reduction after planktivorous fish reduction in a shallow, eutrphic lake: a combined effect of reduced internal P-loading and increased zooplankton grazing. Hydrobiologia 200(201): 229-240.

Søndergaard, M., E. Jeppesen, T. L. Lauridsen, C. Skov, E. H. Van Nes, R. Roijackers, E. Lammens \& R. Portielje, 2007. Lake restoration: successes, failures and long-term effects. Journal of Applied Ecology 44: 1095-1105.

Publisher's Note Springer Nature remains neutral with regard to jurisdictional claims in published maps and institutional affiliations. 